\title{
Review article: Between the Round Table and the Waiting Room: Scholarship on War and Peace in Bosnia-Herzegovina and Kosovo after the 'Post-Cold-War'
}

Catherine Baker

University of Hull

Robert M. Hayden, From Yugoslavia to the Western Balkans: Studies of a European

Disunion, 1991-2011 (Leiden: Brill, 2013). ISBN 978-9004241909. €146.00 (Hardback).

Robert J. Donia, Radovan Karadžić: Architect of the Bosnian Genocide (Cambridge:

Cambridge University Press, 2015). ISBN 978-1107423084. £22.99 (Paperback).

Elton Skendaj, Creating Kosovo: International Oversight and the Making of Ethical

Institutions (Ithaca, NY: Cornell University Press, 2014). ISBN 978-0801452949. \$49.95

(Hardback).

Adam Moore, Peacebuilding in Practice: Local Experience in Two Bosnian Towns (Ithaca, NY: Cornell University Press, 2013). ISBN 978-0801451997. \$45.00 (Hardback).

Ian P. Jones and Louise Askew, Meeting the Language Challenges of NATO Operations: Policy, Practice and Professionalisation (Basingstoke: Palgrave Macmillan, 2014). ISBN 978-1349457328. £63.00 (Paperback).

Stef Jansen, Čarna Brković and Vanja Čelebičić (ed.), Negotiating Social Relations in Bosnia and Herzegovina: Semiperipheral Entanglements (London and New York: Routledge, 2017). ISBN 978-1472454386. £105.00 (Hardback).

The Yugoslav wars of the 1990s are a turning point in the history of diplomacy and international relations between the end of the Cold War and the start of the War on Terror. European politicians' failure to exert enough influence or moral leadership to realise their hopes of a new diplomatic role for European powers made the wars in Croatia and BosniaHerzegovina a sad counterpoint to celebrations of German reunification and the Maastricht Treaty in 1990-2. ${ }^{1}$ A generation of junior US diplomats in the State Department were marked by their inability to persuade superiors in 1992-5 that the Army of Republika Srpska (VRS) was committing genocide in Bosnia, ${ }^{2}$ and the North Atlantic Treaty Organization (NATO) air strikes against Serbia and Montenegro during the Kosovo War were what compelled the

\footnotetext{
${ }^{1}$ Josip Glaurdić, The Hour of Europe: Western Powers and the Breakup of Yugoslavia (New Haven, CT: Yale University Press, 2011), 1. This review refers to 'Bosnia-Herzegovina' as 'Bosnia' for ease of reading, though specialist literature would usually still refer to 'Bosnia-Herzegovina' or the abbreviation 'BiH'.

${ }^{2}$ Samantha Power, A Problem from Hell: America and the Age of Genocide (London: Harper Perennial, 2003), 314. 
British prime minister Tony Blair to issue the most complete statement of his doctrine of liberal interventionism. ${ }^{3}$ The wars are the subject of a rich specialist literature grounded in the history and anthropology of the region, but also stand as a recent example in longer comparative histories of international intervention. ${ }^{4}$ Scholarship in many disciplines explores the aftermath of the Yugoslav wars; only by viewing these disciplines together, this review argues, can historians see how they relate to one another.

The wars themselves are passing out of the 'instant history' they represented when the first academic and serious journalistic accounts were being written ${ }^{5}$ - 'instant' because they sought to explain wars where the outcome was not even yet known and their conclusions had to remain exceptionally contingent - into a mode of contemporary history where archival research has started being possible and the wars, though still recent, represent a palpably different moment in international security from today. The region's politics today display domestic political disengagement, creeping semi-authoritarianism, endemic socio-economic precarity and ongoing international supervision - far from the optimistic expectations of a 'post-Cold-War' period in European history that increasingly seems to have come to an end.

In academic literature, the wars have thus had parallel afterlives. The historiography of the collapse of Yugoslavia, shaped by anthropologists and other social scientists as much as historians, turns on the ascription of guilt and responsibility and on how far the wars should be explained with reference to ethno-national antagonisms. In Politics and International relations, meanwhile, the comparative study of peacebuilding (plus other forms of postconflict intervention like transitional justice) places Yugoslav successor states, especially Bosnia and Kosovo, among many other case studies of the dynamics, effectiveness and politics of international intervention - often addressing practitioners as well as researchers. ${ }^{6}$ These two scales might seem difficult to reconcile - and yet as peacebuilding scholars have

\footnotetext{
${ }^{3}$ Oliver Daddow, “"Tony's war": Blair, Kosovo and the interventionist impulse in British foreign policy', International Affairs 85:3 (2009), 547-60.

${ }^{4}$ For broader studies of the history of humanitarian intervention, see, e.g., Gary Bass, Freedom's Battle: the Origins of Humanitarian Intervention (New York: Knopf, 2008); Didier Fassin and Mariella Pandolfi (ed.), Contemporary States of Emergency: the Politics of Military and Humanitarian Intervention (Cambridge, MA: MIT Press, 2010); Michael Barnett, Empire of Humanity: a History of Humanitarianism (Ithaca, NY: Cornell University Press, 2011); Brendan Simms and D. J. B. Trim (ed.), Humanitarian Intervention: a History (Cambridge: Cambridge University Press, 2011); Eyal Weizman, The Least of All Possible Evils: Humanitarian Violence from Arendt to Gaza (London: Verso, 2012); Fabian Klose (ed.), The Emergence of Humanitarian Intervention: Ideas and Practice from the Nineteenth Century to the Present (Cambridge: Cambridge University Press, 2016).

${ }^{5}$ Gale Stokes, John Lampe and Dennison Rusinow with Julie Mostov, 'Instant history: understanding the wars of Yugoslav secession', Slavic Review 55:1 (1996), 136-60.

${ }^{6}$ See, e.g., Paula M. Pickering, Peacebuilding in the Balkans: the View from the Ground Floor (Ithaca, NY: Cornell University Press, 2007).
} 
turned towards the everyday, localised and microhistorical, their research increasingly aligned with ethnographers' insights into how international governance and domestic politics had produced the uncertain conditions in which the Yugoslav region finds itself today. Meanwhile - as this review of recent works by historians, political scientists, linguists and anthropologists shows - the historiography of the Yugoslav wars itself became a social fact in the politics of knowledge behind international intervention.

This is the case because many foreign officials who travelled to the Yugoslav region to implement internationally-driven strategies of peacebuilding, transitional justice and democratisation brought assumptions about what had caused the Yugoslav wars and how to prevent them recurring. ${ }^{7}$ What they thought they knew about factors like ethnic antagonism, postsocialist socio-economic precarity, or organised crime, and how much weight to put on each, stemmed in large part from the accounts of the region's history they had encountered. The comparative political scientist of ethnic conflict, Stephen Saideman, once wrote that '[p]erhaps [his] greatest contribution' to US military thinking during a 2001-2 fellowship with the US military's Joint Staff was to persuade its Balkans Branch to stop assigning Robert Kaplan's essentialising travelogue Balkan Ghosts, which he believed gave peacekeepers a harmfully over-simplified context for the conflict. ${ }^{8}$ What interveners understood about post-Yugoslav ethnopolitics - and about the relative importance of ethnicity and other social divides in post-Yugoslav politics - therefore informed their peacebuilding and statebuilding policies, with consequences for how much political agency post-Yugoslav citizens would have after the wars.

Lived experiences of the wars and the postwar peace process have left lasting imprints on the kinds of scholarship produced about the wars. The first two books reviewed here, From Yugoslavia to the Western Balkans: Studies of a European Disunion, 1991-2011 by the lawyer, legal scholar and anthropologist Robert M. Hayden and Radovan Karadžić: Architect of the Bosnian Genocide by the historian Robert J. Donia, have both been shaped in different ways by the politics of post-conflict intervention and justice. ${ }^{9}$ While Hayden seeks to open a

\footnotetext{
${ }^{7}$ See, e.g., Brendan Simms, Unfinest Hour: Britain and the Destruction of Bosnia (London: Allen Lane, 2001); Kimberley Coles, Democratic Designs: International Intervention and Electoral Practices in Postwar BosniaHerzegovina (Ann Arbor, MI: University of Michigan Press, 2007).

${ }^{8}$ Stephen Saideman, 'Beware of officers carrying reading lists,' Saideman's Semi-Spew, 18 April 2011, https://saideman.blogspot.co.uk/2011/04/beware-of-officers-carrying-reading.html?m=0 (accessed 24 May 2017).

${ }^{9}$ Robert M. Hayden, From Yugoslavia to the Western Balkans: Studies of a European Disunion, 1991-2011 (Leiden: Brill, 2013); Robert J. Donia, Radovan Karadžić: Architect of the Bosnian Genocide (Cambridge: Cambridge University Press, 2015).
} 
polemic about what he sees as the hypocrisy of the International Criminal Tribunal for the Former Yugoslavia (ICTY), Donia as a frequent expert witness for the prosecution at the same tribunal was in the almost unique position of being aggressively cross-examined by the subject of his own biography - an experience that gave him a new understanding of the Karadžić behind his documentary evidence. ${ }^{10}$

Hayden's From Yugoslavia to the Western Balkans collects articles Hayden has published on memory politics, 'genocide' discourse, the Tribunal, and Bosnian constitutional politics over the past two decades; the early chapters function in the volume both as document and prediction. Donia's Karadžić, meanwhile, is a new biographical monograph drawing upon newly released evidence that the Tribunal's prosecutors collected for the trials of Karadžić and other defendants. The two books differ vastly in subject matter and methodology, but both studies reveal ways that politics and polemics from the early 1990s (when the authors took opposed positions on Bosnian independence) have become mapped on to scholarly debates, such as their diametrically opposed conclusions about the Tribunal: Donia is an experienced expert witness for the prosecution, Hayden a long-time critic of the Tribunal and an expert witness in the defence of Dušan Tadić, the Tribunal's first defendant whose case went to trial. ${ }^{11}$ Among the many matters on which they disagree are their understanding of how constructions of ethnic identity of territory led to wars of civilian persecution, and the question of what can or should be acknowledged as genocide. These matters remain politically and diplomatically sensitive, but also academically contentious.

Hayden has, for instance, long believed 'that by classifying recent Yugoslav events as "genocide," the nature of the events themselves is actually obscured rather than explained', and that politicised accusations of genocide during the Bosnian war impeded a quicker end to the conflict. ${ }^{12}$ That quicker end would have been a partition of most or all of Bosnia and Herzegovina between Serbia and Croatia, in accordance with what Hayden's reading of the eve of war would see as Bosnian Serbs' and Herzegovinan Croats' majority wishes. More recently, Hayden has argued that laws against genocide denial represent a secular 'criminalization of [...] unorthodox views' akin to religious punishment of heresy. ${ }^{13}$ For Donia, however, there is no doubt that political and military proponents of Republika Srpska

\footnotetext{
${ }^{10}$ Donia, Karadžić, 2-6. The ICTY is hereafter 'the Tribunal', though specialist literature is more likely to use the acronym.

${ }^{11}$ Hayden, From Yugoslavia, 223. Hayden's role was to offer testimony on the question of whether the Bosnian war had been a national or international conflict.

12 Hayden, From Yugoslavia, 117, 140-1.

${ }^{13}$ Hayden, From Yugoslavia, 241.
} 
(RS), the entity that declared itself a Bosnian nation-state and sought to expel non-Serbs from its territory, committed genocide. While he does not adopt the maximalism of historians such as Edina Bećirević, who argues that Karadžić's entire campaign against Bosniaks in 1992-5 should count as genocide, Donia contends that 'broad judicial and popular agreement' recognises the massacres of 8,372 Bosniak men and boys at Srebrenica in July 1995 as genocide. ${ }^{14}$ Throughout the book, Donia unambiguously names this a 'Bosnian Genocide' and Karadžić, equally indubitably, its 'architect' ${ }^{15}$ Srebrenica is where Hayden comes closest to referring to any part of the Bosnian conflict as genocide, though even then his language remains conditional. ${ }^{16}$ While it would be reductive, as Christian Axboe Nielsen argues, to reduce the Yugoslav wars' historiography entirely to 'a "genocide or not" dichotomy', ${ }^{17}$ the gulf between Hayden's and Donia's approaches to genocide, perhaps even more than their conclusions about Bosnian independence in 1992, reveals two very different conceptions of the scholar's task: the reader must determine how far these stem from the authors' different disciplinary traditions.

Hayden's collection comprises fifteen previously published articles, plus a new coda, 'From EUphoria to EU-goslavia', extending his long-standing contention that 'multinational polities in Europe have a history of not functioning' into an argument - written years before Brexit had become a mainstream British political option - that the inherent instability of a Yugoslav federation built from ethno-national republics under a fictitious pan-Yugoslav identity has ominous lessons for the European Union's stability. ${ }^{18}$ The chapters combine pieces as widely debated as 'Schindler's Fate', Hayden's polemical 1996 essay on forced population transfers in 20th-century history, ${ }^{19}$ with newer articles about the impossibility of reaching a Bosnian constitutional settlement acceptable to majorities in all three ethnic groups, older book chapters on the distortion of Second World War body counts in late socialist Yugoslavia, and a group of articles on the hypocrisy of international 'humanrightsism' that usefully allows his current perspective on the Tribunal to be read in the

\footnotetext{
${ }^{14}$ See Edina Bećirević, Genocide on the Drina River (New Haven, CT: Yale University Press, 2014).

${ }^{15}$ Donia, Karadžić, 18.

${ }^{16}$ Hayden writes: "That mass slaughter may have put, finally, some accuracy into the charges of "genocide" that had been made since the very start of the conflict, thus turning "genocide" from politically-inspired label to selffulfilling prophecy' (From Yugoslavia, 141).

${ }^{17}$ Christian Axboe Nielsen, 'Surmounting the myopic focus on genocide: the case of the war in Bosnia and Herzegovina', Journal of Genocide Research 15:1 (2013), 21-39, 21.

${ }^{18}$ Hayden, From Yugoslavia, 387.

${ }^{19}$ See Diane P. Koenker (ed.), 'Discussion: "Schindler's fate: genocide, ethnic cleansing, and population transfers"', Slavic Review 55:4 (1996), 727-78, especially Hayden's original article and the most critical response by Carol Lilly.
} 
context of criticisms Hayden was already making of Helsinki Watch/Human Rights Watch in 1990. Though not written as a single integrated narrative of the conflict, the chapters can be read as a compendium of arguments that have left a mark on theoretical discussions of the wars by claiming to bridge legal scholarship and an anthropologist's 'holistic approach' ${ }^{20}$ One distinctive feature of Hayden's approach, his interest in comparing Yugoslavia and India, deserves revisiting now that new scholarship on the global Cold War is bringing Yugoslav-Indian relations through the Non-Aligned Movement further into light.

If the main points of Hayden's scholarship are collected here, so too are what his critics claim to be his most serious contextual omissions. ${ }^{21}$ The first is Hayden's take on the breakup of the federal League of Communists in January 1990. He largely blames the Slovenian and Croatian parties without describing how Slobodan Milošević (who held significant power over the votes of Serbia, Kosovo, Vojvodina and Montenegro) had shaken the balance of power by revoking the provincial autonomy of Vojvodina and Kosovo and repressing Kosovo Albanians' civil rights. Many Slovenes and Croats started fearing that they might share this fate.

Hayden's implication that Bosnians of different ethnicities had never demanded to live together in a sovereign Bosnian state has also drawn criticism, for not accommodating the forms of Bosnian belonging, across and beyond ethnic boundaries, that existed as social alternatives until nationalist political coalitions and outright violence suppressed them. For example, Hayden's chapter on 'The Partition of Bosnia', originally written in May 1993, speaks throughout of Muslims, Croats and Serbs, never of multi-ethnic or non-ethnic forms of political community - yet, as more recent social and intellectual histories of late socialist Bosnia show, ${ }^{22}$ such demands for political community were being made in Bosnia on the eve of war. But these alternative voices were suppressed politically by nationalists and physically by the snipers who fired on a multi-ethnic peace demonstration in Sarajevo on 5 April 1992 a demonstration called to celebrate international recognition of the very independence for

\footnotetext{
${ }^{20}$ Hayden, From Yugoslavia, xii.

${ }^{21}$ See, e.g., Carol S. Lilly, 'Amoral realism or immoral obfuscation?’, Slavic Review 55:4 (1996), 749-54; Thomas Cushman, 'Anthropology and genocide in the Balkans: an analysis of conceptual practices of power', Anthropological Theory 4:1 (2004), 5-28; Sabrina P. Ramet, Thinking About Yugoslavia: Scholarly Debates about the Yugoslav Breakup and the Wars in Bosnia and Kosovo (Cambridge: Cambridge University Press, 2005).

${ }^{22}$ See, e.g., Neven Andjelić, Bosnia-Herzegovina: the End of a Legacy (London: Frank Cass, 2003); Dalibor Mišina, Shake, Rattle and Roll: Yugoslav Rock Music and the Poetics of Social Critique (Farnham: Ashgate, 2013); Ljubica Spaskovska, The Last Yugoslav Generation: the Rethinking of Youth Politics and Cultures in Late Socialism (Manchester: Manchester University Press, 2017).
} 
which Hayden has contended there was no mass Bosnian demand. ${ }^{23}$ While 'the terminologies of description used since 1991 by the peoples of Bosnia and Herzegovina to describe themselves' might indeed have made 'Bosnians' by that name a 'vanishing category', ${ }^{24}$ those terminologies were the product of political processes which had deliberately undermined the space where such a category could exist. Those who eschewed ethnic political identities had the least access to political and diplomatic, let alone military, power.

Donia's study of Karadžić, meanwhile, is less a traditional biography, more the most exhaustive account in English of how Karadžić and the Serb Democratic Party (SDS) planned and orchestrated their campaign. Donia shows how the SDS first monopolised power in Serbmajority municipalities during autumn 1991, then how they founded an 'Autonomous Region of Krajina' using a plebiscite boycotted by most non-Serbs, and finally how they unleashed a campaign of paramilitary and military violence against non-Serbs and politically unwelcome Serbs. In developing his biography, Donia makes use of a complete set of transcripts from the Bosnian Serb Assembly, hundreds of telephone intercepts that security services in the Republic of Bosnia-Herzegovina began collecting in May 1991, SDS internal documents, diaries written by Ratko Mladić (which Serbian investigators found in his Belgrade apartment in 2010), Karadžić's own speeches, and other major ideological documents in the history of the Yugoslav wars, such as the Serbian Academy of Arts and Sciences memorandum of 1986 or the Slovenian Nova revija manifesto of 1987. Indeed, Donia places Karadžić's 'six strategic goals' speech of 12 May 1992 (prima facie evidence that the SDS's takeovers of towns and villages were part of a planned programme of territorial expansion and control, not just spontaneous 'hatred') among these as a key document for understanding the wars. In pursuit of this programme, Donia unwaveringly shows, 'Radovan Karadžić planned, ordered, monitored, and sought to justify the Srebrenica genocide' of July 1995 'with forethought, decisiveness, and calm detachment'. ${ }^{25}$ While letting judges determine criminal responsibility, ${ }^{26}$ Donia attributes moral responsibility as firmly as a historian can: a necessary statement about crimes which two decades later are still beset by obfuscation.

Whereas Hayden's arguments rest on his observation of the lack of consensus about a Bosnian demos in 1992, Donia shows what processes convinced Bosnians between 1990 and 1992 that only affiliation with the cause of one ethno-national group or another could protect

\footnotetext{
${ }^{23}$ Kemal Kurspahić, Prime Time Crime: Balkan Media in War and Peace (Washington DC: US Institute of Peace Press, 2003), 99; Hayden, From Yugoslavia, xvii.

${ }^{24}$ Hayden, From Yugoslavia, 77-8.

${ }^{25}$ Donia, Karadžić, 250.

${ }^{26}$ Donia, Karadžić, 17.
} 
them, and what strategies of intimidation were necessary to break the Bosnian polity apart. His focus on the RS and Karadžić supports and extends existing accounts of the immediate background to the Bosnian conflict and the planned, deliberate nature of the violence committed in pursuit of an ethnically pure Serb state; ${ }^{27}$ historians would be well served if other parties such as the Bosnian Croat 'Herceg-Bosna' entity or Fikret Abdić's Bihać enclave received such exhaustive treatment.

In using so much Tribunal documentation, Donia's study also joins an expanding literature on the Tribunal and its prosecutorial strategy. ${ }^{28}$ The politics of how and why the Tribunal was formed, how it operated, what parties it chose (not) to investigate (Hayden rightly asks why NATO commanders were not investigated for using cluster munitions over Serbia and Montenegro in $1999^{29}$ ), and how prosecutors and defence lawyers actively deployed historical evidence in constructing cases are all part of the context of how such evidence became available to historians. This archival methodology is very different from Hayden's interpretive use of legal and anthropological theory. Both authors also differ in how and when their narratives begin, and in their perspectives on the viability of a multi-ethnic Bosnian state. However, they have one thing at least in common: both explain how the Bosnian war was driven by conflicts over how the ethnic identity of a piece of territory should be determined and which nation's right to sovereignty should then hold sway. . While historians have investigated these linkages between ethnicity, territory and sovereignty in order to reach a deeper understanding of nationalism and genocide in contemporary European history, research in the field of peacebuilding explores a similar configuration of factors in order to solve practical problems on the ground. But, as the following section will suggest, historians interested in both the regional history of the Yugoslav wars and global histories of international intervention might benefit from the insights offered by research into peacebuilding.

The field of peacebuilding research is itself a product of the post-conflict intervention of the 1990s, and has focused intensively on Bosnia and Kosovo as case studies. While scholars of south-east European area studies have been preoccupied by ethnicity and nationalism, the central question for the study of peacebuilding is how to prevent a return to violence and

\footnotetext{
${ }^{27}$ Andjelić, Bosnia-Herzegovina; Marko Attila Hoare, How Bosnia Armed (London: Saqi, 2004).

${ }^{28}$ James Gow, The Serbian Project and its Adversaries: a Strategy of War Crimes (London: Hurst, 2003); Richard Ashby Wilson, Writing History in International Criminal Trials (Cambridge: Cambridge University Press, 2011).

${ }^{29}$ Hayden, From Yugoslavia, 215.
} 
what constitutes 'peace'. In the mid-2000s, a new wave of peacebuilding scholars became fascinated by the everyday and micropolitical dimensions of peacebuilding, bringing the field closer to ethnographic and historical modes of perception. This 'local turn' emerged in response to postcolonial, Marxist, ${ }^{30}$ or purely pragmatic critiques of Western interventionist notions of the 'liberal peace' espoused by British and US governments (and many others) after the Kosovo War and the beginnings of the wars in Iraq and Afghanistan. ${ }^{31}$ The 'local turn' approach to peacebuilding focused on exploring 'hybrid' forms of peace resulting from interactions between local and international actors, and on understanding 'everyday' forms of peace-making among local civil society or grassroots organisations. ${ }^{32}$ Kosovo and/or Bosnia are quite common examples in theoretical studies of hybrid or everyday peace. ${ }^{33}$ This new literature on the practices of peacebuilding draws on ethnographic approaches and microhistorical analysis, and may offer historians new insights into the exercise of power and knowledge in international intervention.

The next three works reviewed exemplify this turn to the 'local', and focus in particular on the barriers that prevent international peacebuilders gaining enough 'local' knowledge to bring about or even comprehend what inhabitants of post-conflict societies might perceive as peace. Peacebuilding scholars became more conscious of this question after the publication of Séverine Autesserre's Peaceland: Conflict Resolution and the Everyday Politics of International Intervention in 2014, though it echoes questions that anthropologists had already been raising. ${ }^{34}$ Elton Skendaj's Creating Kosovo: International Oversight and the Making of Ethical Institutions focuses on the United Nations Interim Administration in Kosovo (UNMIK). Unlike the layers of Bosnian civil administration under international

\footnotetext{
${ }^{30}$ On Bosnia in this vein, see David Chandler, Bosnia: Faking Democracy after Dayton, 2nd ed. (London: Pluto, 1999).

${ }^{31}$ See Roger Mac Ginty and Oliver Richmond, 'The local turn in peace building: a critical agenda for peace', Third World Quarterly 34:5 (2013), 763-83; Caroline Hughes, Joakim Öjendal and Isabell Schierenbeck (ed.), 'The "local turn" in peacebuilding: the liberal peace challenged', special issue of Third World Quarterly, 36:5 (2015).

${ }^{32}$ See Roger Mac Ginty, International Peacebuilding and Local Resistance: Hybrid Forms of Peace (Basingstoke: Palgrave Macmillan, 2011); Roger Mac Ginty, 'Everyday peace: bottom-up and local agency in conflict-affected societies', Security Dialogue 45:6 (2014), 548-64; Laura McLeod, 'A feminist approach to hybridity: understanding local and international interactions in producing post-conflict gender security', Journal of Intervention and Statebuilding 9:1 (2015), 48-69; Roger Mac Ginty and Oliver Richmond, 'The fallacy of constructing hybrid political orders: a reappraisal of the hybrid turn in peacebuilding', International Peacekeeping 23:2 (2016), 219-39.

${ }^{33}$ E.g., Mac Ginty, International Peacebuilding, contains chapters on Afghanistan, Iraq, Bosnia, Lebanon and Northern Ireland. Bosnia represents a case of 'hybrid statebuilding' (p. 134), where the legacies of wartime and pre-war (socialist Yugoslav) statebuilding projects can be said to have hybridised with peacebuilders' intentions for Bosnia at Dayton.

${ }^{34}$ Séverine Autesserre, Peaceland: Conflict Resolution and the Everyday Politics of International Intervention (Cambridge: Cambridge University Press, 2014).
} 
oversight created by the Dayton Peace Agreement of December 1995, civil administration in Kosovo was wholly the responsibility of UNMIK until local politicians, frustrated at the length of time it was taking to negotiate a road-map to independence with Serbia, issued a unilateral declaration of independence in 2007 and passed a new constitution in 2008.

Skendaj provides locally grounded - and historically informed - analyses of attempts to reconfigure public institutions in order to create democracy, peace and liberal reform in postconflict Kosovo. ${ }^{35}$

Peacebuilding in Kosovo was shaped both by the liberal interventionism of Blair and the 'Bosnia generation' of US diplomats, and by Western disillusionment after the failure of utopian statebuilding in 2000s Afghanistan and Iraq. Skendaj's Creating Kosovo uses questionnaires and interviews with reformers of Kosovo's police, customs service, central state bureaucracy and courts in order to test the hypothesis that placing state institutions under 'local' control too early is not effective in achieving interveners' goals. ${ }^{36}$ Skendaj concludes that the state bodies that enjoyed most public confidence, operated most effectively and were least vulnerable to corruption were those which international institutions had most successfully insulated from the local political system (the customs service and police); those with the most local ownership, the judiciary and central administration, were most vulnerable to political patronage and least trusted by citizens.

Skendaj's account of politics in Kosovo might interest historians firstly because it traces the legacies of socialist, pre-war state structures into wartime and post-war Kosovo, which some presentist peacebuilding research might not take into account. Secondly, it shows that political clientelism, more than ethnicity, determined Albanians' political position: in particular, ex-members of the Kosovo Liberation Army (KLA), led by Hashim Thaçi, and their regional clients from the Drenica Valley, came to be at odds with networks from the Democratic League of Kosovo (LDK), the party that had aligned with Kosovo's branch of the Socialist Alliance for Working People to lead non-violent resistance to Milošević. ${ }^{37}$ Skendaj does not fully develop the historical explanation of patronage that his background about the

\footnotetext{
${ }^{35}$ Elton Skendaj, Creating Kosovo: International Oversight and the Making of Ethical Institutions (Ithaca, NY: Cornell University Press, 2014); Gëzim Visoka, Peace Figuration after International Intervention: Intentions, Events and Consequences of Liberal Peacebuilding (London and New York: Routledge, 2016).

${ }^{36}$ See Timothy Donais, Peacebuilding and Local Ownership: Post-Conflict Consensus-Building (London and New York: Routledge, 2012), which contains case studies of Bosnia (as 'ownership by imposition?'), Afghanistan and Haiti; Roland Paris, At War's End: Building Peace after Civil Conflict (Cambridge: Cambridge University Press, 2004), which used the September 1996 national elections in Bosnia (less than a year after Dayton) as one of its main case studies to argue that early 'local' control of state institutions weakened rather than strengthened peacebuilding.

${ }^{37}$ Skendaj, Creating Kosovo, 41.
} 
KLA and LDK factions might invite; it is sufficient, for his purposes, to know that it exists. The histories of why NATO challenged Milošević in 1999 or why the UN took over Kosovo's international administration afterwards are, likewise, mostly outside its remit, to the point that the background narrative at one point describes 'NATO soldiers', not UN ones, as responsible for failing to prevent 'mass murder' at Srebrenica in $1995 .{ }^{38}$ Creating Kosovo exemplifies a problem-solving approach to peacebuilding and democratisation, oriented towards improving future interventions as much as, or more than, explaining how Kosovo's current condition came to be.

Despite the tendency towards theoretical abstraction in some peacebuilding research, some studies succeed in conveying the spatial and historical nuances of a post-conflict society. Adam Moore's Peacebuilding in Practice: Local Experience in Two Bosnian Towns, based on ethnographic observation, archival research and 120 interviews collected during visits to Brčko and Mostar in 2004-12, compares two Bosnian cities in ostensibly similar circumstances (both were and are the subjects of ethno-territorial disputes that stemmed from the war and have persisted since Dayton) where peacebuilding has nevertheless had different outcomes and where international-local relationships, Moore finds, have also had a different character. ${ }^{39}$

While Mostar remains contested between the Croatian Democratic Union (HDZ), which has monopolised the urban space and economy of western Mostar, and the Bosniak nationalist Party of Democratic Action (SDA), with its power base in the east of the city, negotiators at Dayton could not agree whether to award Brčko (a pinchpoint between the northern and eastern halves of the RS) to the RS or the Federation. The Brčko Final Award of March 1999, announced by a US administrator, made the Brčko District a distinct multiethnic government (on Federation and RS territory but under the authority of neither). Its political system was deliberately designed to promote political and social integration, eschewing the institutionalised ethnic power-sharing approach that Dayton had applied to the rest of Bosnia, including Mostar. Brčko would go on to have Bosnia's only integrated school system, whereas the obstacles to integrating even one school in Mostar - let alone to using its integration as a platform for reintegrating social interaction in the rest of the city - are richly described by Azra Hromadžić's ethnography of the Mostar Gymnasium. ${ }^{40}$ Mostar is, after

\footnotetext{
${ }^{38}$ Skendaj, Creating Kosovo, 49.

${ }^{39}$ Adam Moore, Peacebuilding in Practice: Local Experience in Two Bosnian Towns (Ithaca, NY: Cornell University Press, 2013).

${ }^{40}$ Azra Hromadžić, Citizens of an Empty Nation: Youth and State-Making in Postwar Bosnia-Herzegovina (Philadelphia, PA: University of Pennsylvania Press, 2015).
} 
Sarajevo and Srebrenica, probably the most commonly researched city in post-war Bosnia; ${ }^{41}$ there are fewer studies of Brčko, yet those that exist all suggest the ethnicity-territory nexus operated somewhat differently in social and political practice there. ${ }^{42}$ Moore's study is thus another example of how recent research into Bosnian towns' and cities' specific historical and socio-economic contexts has helped historians to understand the multiple and localised conflicts that combined to constitute the war in Bosnia. ${ }^{43}$

The power and authority of international agencies was also, Moore shows, constituted through localised interactions and thus operated in different ways across the country. Moore, like Visoka, is interested in emergent 'configurations' of power, ${ }^{44}$ and his greater level of localised texture further illustrates them. The strategy that the Office of the High Representative (OHR) in Brčko found for achieving its integrative peacebuilding aims depended on acting as a patron for local political and economic interests vis-à-vis OHR Sarajevo, which in 2002-6 under Paddy Ashdown sought to bring the Brčko office under its direct control. ${ }^{45}$ By shifting supervision of Brčko to Sarajevo in 2007, the OHR lost the 'intimate knowledge of current developments in the District $-[\ldots]$ the product of intensive daily interactions with local officials' which until then appeared to have set peacebuilding in Brčko apart, at least on an institutional level: it was little wonder, Moore suggests, that local support for the OHR's presence in Bosnia had declined to 15 per cent by $2010 .{ }^{46}$

\footnotetext{
${ }^{41}$ See also, e.g., Carl Grodach, 'Reconstituting identity and history in post-war Mostar, Bosnia-Herzegovina', City 6:1 (2002), 61-82; Larissa Vetters, 'The power of administrative categories: emerging notions of citizenship in the divided city of Mostar', Ethnopolitics 6:2 (2007), 187-209; Richard Mills, 'Velež Mostar Football Club and the demise of "brotherhood and unity" in Yugoslavia, 1922-2009', Europe-Asia Studies 62:7 (2010), 1107-33; Annika Björkdahl and Ivan Gusić, 'Sites of friction: governance, identity and space in Mostar', in Peacebuilding and Friction: Global and Local Encounters in Post-Conflict Societies, ed. Annika Björkdahl, Kristine Höglund, Gearoid Millar, Jaïr van der Lijn and Willemijn Verkoren (London and New York: Routledge, 2016), 84-102; Aleksandra Djurasović, Ideology, Political Transitions and the City: the Case of Mostar, Bosnia and Herzegovina (London and New York: Routledge, 2016); Monika Palmberger, How Generations Remember: Conflicting Histories and Shared Memories in Post-War Bosnia and Herzegovina (London: Palgrave Macmillan, 2016); Andrea Connor, The Political Afterlife of Sites of Monumental Destruction: Reconstructing Affect in Mostar and New York (London and New York: Routledge, 2017). Florian Bieber, 'Local institutional engineering: a tale of two cities, Mostar and Brčko', International Peacekeeping 12:3 (2005), 420-33, had previously recognised the comparative potential of Brčko and Mostar and reached conclusions that would be borne out, after eight more years of contentious politics, by Moore's research. ${ }^{42}$ See, e.g., Alex Jeffrey, 'Building state capacity in post-conflict Bosnia and Herzegovina: the case of Brčko District', Political Geography 25:2 (2006), 203-27; Carl Dahlman and Gearóid Ó Tuathail, 'Bosnia's third space?: nationalist separatism and international supervision in Bosnia's Brčko District', Geopolitics 11:4 (2006), 651-75. Janine Natalya Clark, 'Bosnia's success story?: Brčko District and the "view from below"', International Peacekeeping 17:1 (2010), 67-79, argues based on interviews with 10 residents of Brčko in 2009 that the institutional 'success' of peacebuilding had not in itself produced the bonds of everyday inter-ethnic trust that one might have expected to find in a less 'thin', socially meaningful reconciliation (p. 73).

${ }^{43}$ See, e.g., Ioannis Armakolas, 'The "paradox" of Tuzla City: explaining non-nationalist local politics during the Bosnian war', Europe-Asia Studies 63:2 (2011), 229-61.

${ }^{44}$ Moore, Peacebuilding in Practice, 6.

${ }^{45}$ Moore, Peacebuilding in Practice, 144-5.

${ }^{46}$ Moore, Peacebuilding in Practice, 156-7.
} 
What distinguishes Peacebuilding in Practice from peacebuilding studies with a wider and more abstract lens is not only its richer post-war context but its attention to how wartime legacies in both cities structured political and social conditions, which is also an important foundation for historians considering the legacies of war. If knowledge of the conflict in Mostar between the Croat Defence Council (HVO) and the Army of the Republic of BosniaHerzegovina (ARBiH), representing the government in Sarajevo, and of how HDZ elites monopolised the privatisation of Party-owned factories, is essential for understanding the division of post-war Mostar, so too is the less well-known history behind the unpopularity of SDA among its ostensible Bosniak constituency in Brčko - dating back to the day in May 1992 when the SDA's president in Brčko, Mustafa Ramić, was forced to appear on television with a commander from the Yugoslav People's Army (JNA) to reassure non-Serbs there was no need to leave Brčko just as Serb paramilitaries were entering the town to round them up. ${ }^{47}$ These were self-evidently part of the everyday contexts that peacebuilders in each city would find.

And yet, in the practice of international intervention, such nuances are often ignored. Intervention agencies assume that strategies for conflict resolution and stabilisation can be duplicated in any post-conflict situation. A major reason for this absence of institutional contextual knowledge is that international interveners do not speak local languages, and thus have no access to everyday cultural knowledge. ${ }^{48}$ Autesserre argues precisely this in Peaceland - and, indeed, six years before, the anthropologist Andrew Gilbert had similarly argued after ethnographic research with the Organization for Security and Co-Operation in Europe (OSCE) in Bosnia that the OSCE obtained an inaccurate picture of Bosnian politics and society because it devalued local staff's expertise and privileged knowledge that could be easily expressed in English within the genre of a conventional written report. ${ }^{49}$ Mediation between languages is fundamental to the practice of peacebuilding yet almost always taken for granted by peacebuilders themselves. ${ }^{50}$

Most international staff of intervention agencies never acquire linguistic fluency, many do not even seek to, and many organisations would not even keep them in post long enough to acquire it. The mostly locally-recruited language intermediaries on whom they depend for

\footnotetext{
${ }^{47}$ Moore, Peacebuilding in Practice, 83.

${ }^{48}$ Autesserre, Peaceland, 118.

${ }^{49}$ Andrew Gilbert, 'Foreign authority and the politics of impartiality in postwar Bosnia-Herzegovina', $\mathrm{PhD}$ thesis, University of Chicago, 2008; Autesserre, Peaceland, 118.

${ }^{50}$ Hilary Footitt and Michael Kelly (ed.), Languages at War: Policies and Practices of Language Contacts in Conflict (Basingstoke: Palgrave Macmillan, 2012).
} 
written translation and spoken interpreting - much more complex tasks than many nonlinguists are likely to appreciate - are relied upon as unofficial cultural brokers and mediators while in post yet, paradoxically, overlooked as exercisers of agency even in most peacebuilding research. Ian Jones and Louise Askew's Meeting the Language Challenges of NATO Operations, the next work reviewed, provides what very few studies of peacebuilding even attempt to acknowledge, let alone foreground: recognition that the knowledge production and therefore the effectiveness of peacebuilding depends on - that the relationships between 'international' and 'local' at the heart of peacebuilding research are actually constituted by - acts of mediation between languages.

In Meeting the Language Challenges of NATO Operations, Jones and Askew, as professional linguists who worked in NATO's field language services in Bosnia, Kosovo, and then Afghanistan, combine their first-hand experiences as NATO insiders with scholarly analysis of 'the mechanics of language policy formulation in an international organisation." They also show that NATO's operational language policy developed in the wider context of NATO's search for a new purpose in international security after the reunification of Germany and the collapse of the USSR in $1991 .^{52}$ Russian contributions to peace enforcement in Bosnia, for instance, represented the first 'operational cooperation' between NATO and Russian forces, requiring linguists to create a new Russian military vocabulary for NATO concepts such as command and control. ${ }^{53}$

Jones and Askew's detailed accounts of establishing and managing the field language services reveal a history of technological change that improved the workflows of predictable office-based translation between the 1980s and the late 2000s but did not solve the complexities of translation and interpreting in post-conflict peacebuilding, where documents containing significant knowledge rarely materialised in pristine, machine-readable form. HQ SFOR's word processing software in the late 1990s, for instance, could not even accommodate the Cyrillic script in which Serbian was often printed (the very kind of everyday barrier to knowledge circulation that Autesserre and Gilbert so often observed). ${ }^{54}$ The failure of NATO or SFOR commanders to appreciate how heavily their operations depended on accurate and effective translation and interpreting is evident from the fact that it took SFOR two years to invite the professional chief of NATO's own language service to

\footnotetext{
${ }^{51}$ Ian P. Jones and Louise Askew, Meeting the Language Challenges of NATO Operations: Policy, Practice and Professionalisation (Basingstoke: Palgrave Macmillan, 2014), 2.

52 Jones and Askew, Meeting the Language Challenges, 23.

53 Jones and Askew, Meeting the Language Challenges, 45.

${ }^{54}$ Jones and Askew, Meeting the Language Challenges, 57, 75.
} 
even make recommendations about how language support ought to be organised in Bosnia; once Jones had devised a plan for centralising and upgrading SFOR's language service, including relatively much more employment security and professional development than locally-recruited linguists at other military and civilian intervention agencies enjoyed, it took three further years for him to be invited to review the language service in Kosovo. ${ }^{55}$

Meeting the Language Challenges contributes to scholarship on the micropolitics of international intervention by drawing attention to the agency, and the positionality, of language intermediaries themselves within the dynamics of knowledge production in international intervention and the everyday performances of power and security through which intervention takes place. At the same time, the study is itself a product of knowledge production within an international organisation: Jones and Askew were both part of institutional structures which depended on acquiring and applying 'local' knowledge, before they came to write those structures' history. Readers used to the conventions of anthropological or feminist research might expect longer reflections on how some interviewees' working histories as subordinates of Jones or Askew would affect the interview dynamic, or how interview-based methodologies themselves might be limited in what knowledge they can collect about patronage and the informal economy, than this book provides. Historians might develop broader structural arguments around the placement of one expert figure at the centre of the narrative. Yet the fact that a history of NATO's field language services can even be contained within one expert's experiences reflects the lack of awareness throughout NATO and its missions about how language and interlinguistic mediation affect knowledge-gathering and interoperability: a history of NATO logistics, civil-military co-operation or intelligence could not be told this way. While the book does not systematically connect its findings with the diplomatic history of NATO or the transition from Cold War to post-Cold-War, it will be an invaluable resource when an archival history of NATO language policy comes to be written.

The final volume reviewed here, Stef Jansen, Čarna Brković and Vanja Čelebičić's Negotiating Social Relations in Bosnia and Herzegovina, demonstrates how anthropological perspectives can shed light on questions of interest to both historians and peacebuilding practitioners or researchers. ${ }^{56}$ Cécile Jouhanneau's chapter on how and when former camp

\footnotetext{
55 Jones and Askew, Meeting the Language Challenges, 80.

${ }^{56}$ Stef Jansen, Čarna Brković and Vanja Čelebičić (ed.), Negotiating Social Relations in Bosnia and Herzegovina: Semiperipheral Entanglements (London and New York: Routledge, 2017).
} 
detainees from Brčko choose to testify publicly about their wartime experience, or Karla Koutková's chapter arguing that the social categories of 'locals' and 'internationals' in international agencies are produced through practice rather than depending inherently on workers' nationality, for instance, align well with debates over testimony and silence in transitional justice, or the emerging literature on the locally-recruited staff of international agencies, respectively. ${ }^{57}$ Other chapters tackle topics such as families' anxieties for the care of their elderly relatives in a healthcare system which owes its catastrophic conditions to the wartime expropriation of state property, the clientelistic post-war development of a market economy and the stagnation of the cantonal government structure built into the Dayton Peace Agreement itself. These approaches were inspired by historically-minded anthropologists who have called attention to the effects of the collapse of Yugoslav state socialism as much as the effects of inter-ethnic conflict, thus inspiring historical reassessments of late state socialism as well as new anthropological and sociological research on the present. ${ }^{58}$ To understand Bosnia (or the rest of the region), the editors write, "we need to go "beyond" the Dayton lens, and particularly its identitarian matrix' of ethnicity. ${ }^{, 59}$

Alongside the 'chronotope of the round table' of peace negotiations, by which the editors denote the mode of defining Bosnia primarily in terms of three fixed and opposed ethnic groups, Jansen, Brković and Čelebičić propose three other modes of representing Bosnia. One is the chronotope of the 'swamp' or semi-periphery, where footing is uncertain and individuals struggle against the 'ever-present threat, of sinking': this recognises the many geopolitical 'in-between' positions ascribed to the region in the past and present and applies a timeframe which is as much 'post-socialist, or perhaps better: post-Cold War and postFordist' as post-conflict. ${ }^{60}$ Another is the chronotope of the 'labyrinth', through which statebuilders believe they have offered a map by holding out the prospect of 'liberalmulticulturalist' transformation within Euro-Atlantic structures, and where '[o]nly the supervisors [...] have the overview that can guide Bosnians to the exit' - the very image of what peacebuilding studies call the liberal peace. ${ }^{61}$ The third is the chronotope of the "waiting

\footnotetext{
${ }^{57}$ Cécile Jouhanneau, 'The discretion of witnesses: war camp memories between politicisation and civility', in Jansen, Brković and Čelebičić (ed.), Negotiating Social Relations, 31-45; Karla Koutková, "“The king is naked": internationality, informality and ko fol state-building', in Jansen, Brković and Čelebičić (ed.), Negotiating Social Relations, 109-21.

${ }^{58}$ Xavier Bougarel, Ger Duijzings and Elissa Helms (ed.), The New Bosnian Mosaic: Identities, Memories, and Moral Claims in a Post-War Society (Aldershot: Ashgate, 2007); Jansen, Brković and Čelebičić, 'Introduction', 10 .

${ }^{59}$ Jansen, Brković and Čelebičić, 'Introduction', 10.

${ }^{60}$ Jansen, Brković and Čelebičić, 'Introduction', 11-15.

${ }^{61}$ Jansen, Brković and Čelebičić, 'Introduction', 16.
} 
room', already in common use in Bosnian political discourse, that represents Bosnia as a society where 'a variety of people are thrown together' by the fact that they are 'waiting for something, and that their progress towards that something is determined by others, who are running the offices behind the closed doors surrounding the waiting room' ${ }^{62}$ These alternative modes of representation reveal a very different picture of the Bosnian demos to the image that Hayden (who finds Jansen too idealistic on this matter ${ }^{63}$ ) believes had already been an illusion in 1992. Once the Dayton negotiators themselves - Western, Bosnian, Serbian and Croatian - agreed on the assumption of an antagonistic ethnic triangle as the only imaginable form of social relations in Bosnia, while wartime political elites remained in power, the political expression of any alternative demos became impossible within the Dayton structure even as the international managers of the 'waiting room' pressured the ethnicised three-part demos to transform.

Negotiating Social Relations thus also makes an essential contribution to the literature on the consequences of the Yugoslav wars in emphasising the temporality of uncertainty as the defining condition of life in post-conflict and post-socialist Bosnia since 1995. The sense of waiting, stuckness, or 'yearning' ${ }^{64}$ that Jansen first observed in ethnographic research with Bosnian refugees subject to temporary protection measures in the European Union during the 1990s (when they did not know if they would be allowed to stay in their new countries or sent back) has also turned out to structure life in Bosnia itself for anyone without the informal connections ('veze' or 'štele') to prosper as part of the post-Dayton elite. ${ }^{65}$

Two decades after the end of the Bosnian conflict, the EU and NATO still seem to hold out Bosnia's movement towards joining these Euro-Atlantic institutions as a long-term strategy for peace, however illusory this hope may be. ${ }^{66}$ Kosovo, meanwhile, occupies an even more tightly enclosed waiting room where the politics of Serbian negotiations with the EU, and Russian instrumentalisation of Kosovo in its own foreign policy, leave no alternative

\footnotetext{
62 Jansen, Brković and Čelebičić, 'Introduction', 17.

${ }^{63}$ Hayden, From Yugoslavia, 343-4.

${ }^{64}$ See Stef Jansen, Yearnings in the Meantime: 'Normal Lives' and the State in a Sarajevo Apartment Complex (New York: Berghahn, 2015).

${ }^{65}$ Stef Jansen, 'The privatisation of home and hope: return, reforms and the foreign intervention in BosniaHerzegovina', Dialectical Anthropology 30:3-4 (2006), 177-99; Stef Jansen, Yearnings in the Meantime: 'Normal Lives' and the State in a Sarajevo Apartment Complex (New York: Berghahn, 2015).

${ }^{66}$ See Danijela Majstorović, Zoran Vučkovac and Anđela Pepić, 'From Dayton to Brussels via Tuzla: post-2014 economic restructuring as europeanization discourse/practice in Bosnia and Herzegovina', Southeast European and Black Sea Studies 15:4 (2015), 661-82.
} 
future in immediate view. Scholars whose careers and disciplines are grounded in the specifics of the Yugoslav region, and scholars who study the Yugoslav region primarily as part of comparative analyses with a global reach, have wrestled with - and contributed to the metahistory of knowledge production about the 1990s wars, their aftermath and the meanings of inter-ethnic relations in contemporary post-Yugoslav societies. These are not separate camps from each other, and indeed are finding increasing amounts of common ground as international peacebuilding researchers discover ways of knowing that anthropologists have long held as common sense. If peacebuilding studies can learn from the interdisciplinary history-anthropology-sociology of the Yugoslav region about how important an understanding of localised contexts and legacies is for appreciating the everyday micropolitics of peace, the juxtapositions which international peacebuilding studies routinely create between the Yugoslav region and other sites of intervention point to a transnational lens on the region's contemporary - and older - history that connects it not just with the rest of Europe but with the whole globe.

The international military and civilian missions in Bosnia, Kosovo, Timor-Leste and Afghanistan, to name only those that appear in the works reviewed here, belong to an optimistic and confident period in the history of international intervention that has already subsided, though semi-transformed structures of international supervision over all four countries still persist. The histories of this moment of intervention that are yet to be written will surely take up among their major themes the production and circulation of knowledge about peace and conflict: this was a milieu where interpretations and conclusions from one conflict zone were routinely translated less appropriately or more appropriately into policy and practice in another, where both 'internationals' and inhabitants of sites of intervention could find themselves travelling through a global political economy of peacebuilding, governance and military power. What perhaps distinguishes the past they describe from the present in which they appear is that the timescale for the Yugoslav region's exit from the 'waiting room' of international oversight, and the form of society or political system it might exit with, has become less clear rather than clearer with the passage of time. The conversion of hope into uncertainty is, in many ways, what marks the waning of the 'post-Cold-War'. 